\title{
'Hand, foot, and mouth disease' associated with Coxsackie A5 virus
}

\author{
T. H. FLEWETT, R. P. WARIN, AND SUZANNE K. R. CLARKE \\ From the Regional Virus Laboratory, Little Bromwich General Hospital, Birmingham, the \\ United Bristol Hospitals, and the Public Health Laboratory, Bristol
}

SYNOPSIS Seven cases are described of highly infectious disease characterized by vesicular eruptions in the mouth and on the hands and feet. In previous outbreaks described in the literature Coxsackie type A16 virus was isolated but from these cases, simiłar clinically, Coxsackie type A5 virus was isolated.

In 1958 Robinson, Doane, and Rhodes described an outbreak of 60 cases of highly infectious disease characterized by vesicular eruptions in the mouth and on the hands and feet. The infection was mild, $56 \%$ of patients showing some degree of fever. Recovery was rapid. Coxsackie type A16 virus was isolated from a high proportion of patients. Probably, however, the first recognition of the syndrome was by Seddon $(1961,1962)$ who described similar cases in New Zealand in early 1957 and reported them to the New Zealand College of General Practitioners in April 1957. No virological studies could be done at that time. Alsop, Flewett, and Foster (1960) described a similar outbreak in the Birmingham conurbation in 1959 and called it 'hand, foot, and mouth disease'. They described 24 cases and were able, through the Epidemic Observation Unit of the College of General Practitioners, to collect reports of 69 others occurring in the British Isles at about the same time. The clinical features were very similar to those described in Toronto, except that the disease appeared to be even milder, only $2 \%$ of patients having fever. Magoffin, Jackson, and Lennette (1961) reported that in the summer of 1959 this syndrome occurred widely in several districts of California, possibly other western states, and Hawaii. With the exception of a patient with vesicles in the mouth only from whom A4 virus was isolated, A16 virus was isolated from the great majority of cases investigated. Its isolation from vesicle fluid as well as faeces by Alsop et al. implies that its association with so many cases is not a chance one.

This report describes three sporadic cases seen in Birmingham and the contiguous town of Walsall in

Received for publication 4 October 1962.
1960, referred by Dr. R. J. F. H. Pinsent and Dr. R. Lindop, and four cases seen in Bristol in 1961. They were similar clinically to those described above, but differed in that Coxsackie A5 and not A16 virus was isolated by inoculation of suckling mice with the faeces of each of them and the vesicle fluid of one.

\section{CLINICAL FINDINGS}

The patients seen in the Birmingham area were A.P., a boy aged 1 year and 2 months, a little girl, E.H., and W.McD., a girl aged 17. Both A.P. and E.H. had vesicles in the mouth and lesions on the palms of the hands and the soles of the feet, and A.P. had vesicular lesions on the buttocks and thighs also. At first these were small and deep seated, but became superficial and flaccid, and ruptured when the skin was thin. The lesions had been present for less than three days when specimens were taken for examination. W.McD. had lesions on the hands and feet only which had been present two days when specimens were taken.

Four patients were seen in Bristol in 1961. Two sisters, M.V.G., aged 2 years and 10 months, and C.F.G., aged 1 year and 2 months, were seen on 24 October 1961 when M.V.G. had had lesions on the hands, feet, and lips for four days. She had not had obvious pyrexia but her mother had thought she did not seem well about the time of onset. C.F.G. had had a similar eruption for one day but no obvious constitutional disturbance. The lesions erupted over a period of two to three days, some 20-30 appearing in M.V.G. and less than 10 in C.F.G. They were present on the skin close to the red margin of the lips, on the backs and fronts of the fingers, thumbs, palms, borders of the feet, heels, and on the toes. There were a few purple-red papules, but most lesions consisted of superficial grey-white, flaccid blisters, with a surrounding red halo varying in size from 2 to $8 \mathrm{~mm}$. (Figs. 1, 2, and 3).

A girl, C.F., aged 2, was seen on 3 November 1961. 


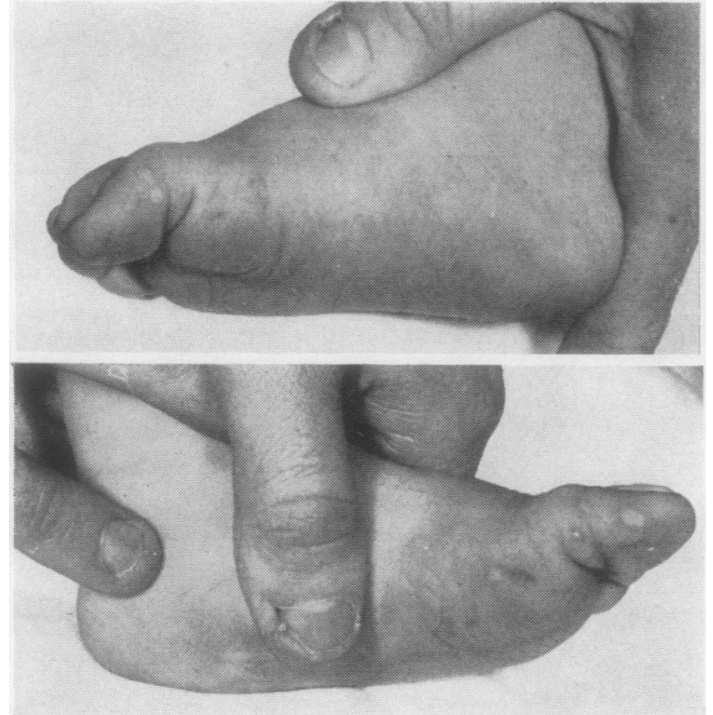

FIG. 1

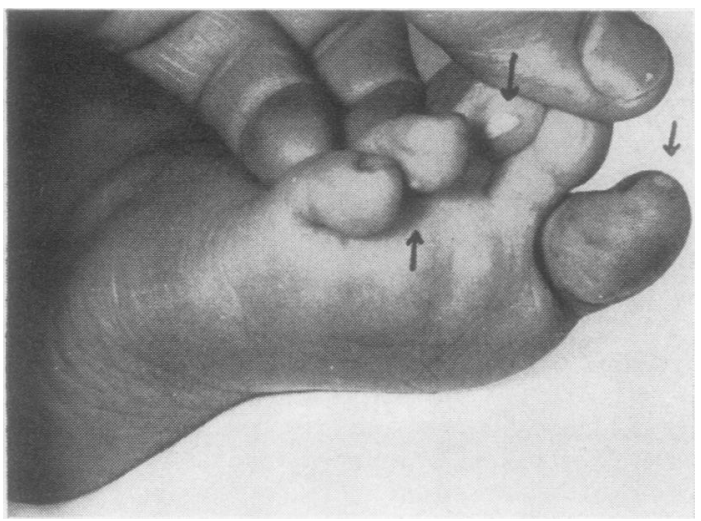

FIG. 2

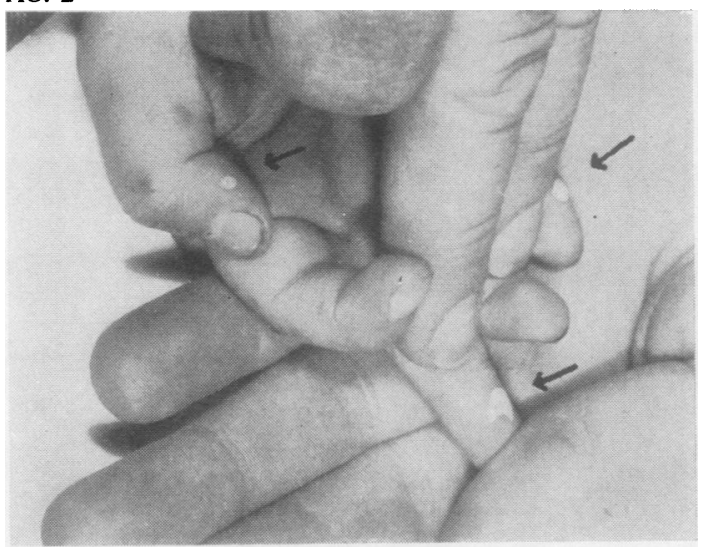

FIG. 3

FIGS. 1, 2, and 3. Hand, foot, and mouth lesions in C.F.G. seen on 24 October 1961 .
She had appeared hot, flushed, and shivering six days $\stackrel{0}{+}$ previously, and four days later had had ulcers in the mouth. On the following day, lesions had developed on. the backs of the hands and for one day she complained of pain on micturition.

On examination she showed some $15-20$ small, white, flaccid blisters over the fingers, hands, and feet. There were three or four ulcers on the buccal mucous membrane? looking very like aphthae. Unfortunately, it was not气 possible to collect a sample of faeces from this patient.

A girl, E.R.N., aged 5, was seen on 19 November 1961 工 She had no obvious constitutional disturbance, but had the same type of eruption on the hands, feet, and on the buccal mucous membrane.

SEROLOGICAL INVESTIGATION (BIRMINGHAM CASES)

Antigens for complement-fixation tests were prepared bythe fluorocarbon Arcton 63 (I.C.I. Ltd., now Arcton 113 $\mathrm{CF}_{2} \mathrm{ClCFCl}_{2}$; freezing point $-35^{\circ} \mathrm{C}$., boiling pointo $47 \cdot 6^{\circ}$ C.) extraction as described by Alsop et al. (1960). Neutralization tests were done by the method recommended by Dalldorf and Sickles (1956) and result@ recorded as $50 \%$ end-points according to Reed and Muench (1938). Virus suspensions were titrated by inocus lation of serial ten-fold dilutions into suckling mice; I.D. ${ }_{50}$ doses were calculated by the method of Reed an 5 Muench (1938). The titre of the A5 virus suspension was found not to be reduced by one Arcton extraction. The mouse carcase suspension used for the neutralizations tests at a dilution of 1 in 100 , as recommended by Dalldorf and Sickles, was found to have an infectivitjă titre of $10^{-6 \cdot 1}$ for suckling mice.

\section{RESULTS}

The results in the Birmingham cases are tabulated below.

\begin{tabular}{|c|c|c|}
\hline Case No. & Neutralization Titre & Complement-fixation \\
\hline 1 Acute phase & $1: 90$ & $<1: 8$ \\
\hline 2 Acute phase & $1: 250$ & $1: 8$ \\
\hline Convalescent phase & $1: 390$ & $1: 32$ \\
\hline
\end{tabular}

\section{DISCUSSION}

Other syndromes associated with Coxsackie group viruses, e.g., aseptic meningitis, herpangina, havæu been found to be associated with more than one serological type of virus, and it is not surprising thaf this is so with 'hand, foot, and mouth disease'.

Coxsackie A5 was isolated also from the faeces of a normal child in Bristol in September 1961 a montb before the occurrence of the Bristol cases. It is of interest that the isolation in this country of A5 virus had not until recently been reported (Gamble, 1962).0

The Bristol cases were all seen by one group o $\bar{P}$ general practitioners, but except for the sisters, the patients lived in widely separated parts of the city It seems likely that knowing the diagnosis of the first 
case they more readily recognized the subsequent ones, and it is felt that other cases may well have been appearing in the city but were not recognized as this condition. One case had few lesions and it is probable that some patients with this disease may have had only one or two blisters and so were not diagnosed. As with most of the previously reported cases the constitutional disturbance was slight. The superficial, flaccid nature of the blisters gives a very characteristic appearance. It is interesting that two cases had lesions on the skin round the mouth and that one patient developed pain on micturition and presumably developed a lesion in or near the urethra.

It had previously been found both by Alsop et al. (1960) and by Magoffin et al. (1961) that surprisingly high antibody titres were present in sera taken shortly after the onset of the disease as caused by A16 virus, though the incubation period seemed to be only five to seven days, as found by Robinson et al. (1958) and by Alsop et al. This observation was further confirmed on investigation of another outbreak of this syndrome in October 1960 involving three families living in adjacent houses, from which several isolations of type A16 virus were made (Flewett and Foster, unpublished). It is interesting that high titres of antibody were also found in sera taken during the acute phase from cases due to type A5 virus. No incubation period could be established for the cases due to the A5 virus, though it seems unlikely that it would differ much from that found with A16 virus infection.

Dr. R. J. F. H. Pinsent and Dr. R. Lindop were the general practitioners concerned with the Birmingham and Walsall cases, Dr. I. L. Maxwell and Dr. N. C. Tricks with the Bristol cases, and we would like to thank them all for their help and interest, and also Dr. D. R. Gamble for typing the Bristol viruses.

We are grateful to Messrs. I.C.I. Ltd. for the physical constants and formula of the fluorocarbon used.

\section{REFERENCES}

Alsop, J., Flewett, T. H., and Foster, J. R. (1960). Brit. med. J., 2, 1708.

Dalldorf, G., and Sickles, G. M. (1956). In Diagnostic Procedures for Virus and Rickettsial Diseases, 2nd ed., p. 153. American Public Health Association, New York.

Gamble, D. R. (1962). Brit. med. J., 1, 16.

Magoffin, R. L., Jackson, E. W., and Lennette, E. H. (1961). J. Amer. med. Ass., 175, 441.

Reed, L. J., and Muench, H. (1938). Amer. J. Hyg., 27, 493.

Robinson, C. R., Doane, F. W., and Rhodes, A. J. (1958). Canad. med. Ass. J., 79, 615.

Seddon, J. H. (1961). Research Newsletter No. 2: Research Committee of New Zealand Council, College of General Practitioners. (1962). Personal communication. 